ESJ Social Sciences

\title{
Absence of Fathers in Childrens' Lives of Divorced Parents: Impact and Implication
}

\author{
Fabjana Bakiu (Maksutaj)
}

University of Tirana, Faculty of Social Sciences, Albania

Doi:10.19044/esj.2021.v17n32p77

Submitted: 02 August 2021

Accepted: 02 September 2021

Published: 30 September 2021
Copyright 2021 Author(s)

Under Creative Commons BY-NC-ND

4.0 OPEN ACCESS

Cite As:

Bakiu M.F. (2021). Absence of Fathers in Childrens' Lives of Divorced Parents: Impact and Implication. European Scientific Journal, ESJ, 17 (32), 77.

https://doi.org/10.19044/esj.2021.v17n32p77

\section{Abstract}

The purpose of this study is to determine through scientific methods to what extent children experience parental divorce and the lack of fathers in families. This paper focuses on measuring the impact it has on adolescent children, between 13-18 years, in Tirana, Albania. Adolescence is one of the most critical stages of life and is very decisive for the future of children. This goal is enabled through the achievement of the following objectives such as: How and to what extent divorce and the lack of father affect the psychoemotional development and perception of children with divorced parents (ChDP) about their future and love relationships; to what extent does the lack of father affect this segment of children, and the identification of consequences to these children. Methodology: This involves a primary survey with the help of a structured questionnaire among children from the age group of 13-18 years in Tirana. The consequences of divorce are theoretically explained and give the opportunity to raise research questions in recent years. Questionnaire is the research instrument which includes questions about the relationship of children with their non-custodial parent, the impact of missing obligations, and the possible consequences for this segment of children. The data are compared with children of the same age, but from intact families, and have led to conclusions and recommendations on social policies to be followed towards this segment in the future.

Keywords: Divorce, lack of father figure, consequences to children, family 


\section{Introduction}

"A developed assessment of emotions is absolutely essential to sociology because no action can take place in a society without emotional involvement" (Jack Barbalet, 2002, p.2) (Cited in: Connor, 2007).

The recent data show that divorce is changing the structure of the family in the last three decades in Albania. Divorce numbers are increasing while marriages are decreasing (INSTAT, Albania). These rates of divorce are affecting the lives of all individuals involved in it. This has a significant effect on the lives of children who are even more fragile to cope with it. The impact is even greater on adolescents that are in search of their identity. It creates a psychological state that makes adolescents of divorced parents negatively perceive their future as adults, as compared to the perceptions of their peers coming from non-divorced families.

Therefore, among a variety of causes that affect this problematic issue, one of the main reasons why the child feels this way is the lack of the father figure in his/her life. For a significant number of the children that participated in the survey this figure is almost non-existent. So, for the healthy development of children fathers, just like mothers, are important attachment figures. However, when divorce happens, this natural habitat of family background is broken and children are left without one of their parents, which in general is the father.

Studies have shown that "one in three children in divorced families are dissatisfied with life, suffer from loneliness or depression, etc." (Beqja \& Sokoli, 2000).

Research shows that fathers often retain an attachment to the breadwinner ideal type (O'Brien \& Shemilt, 2003; Sullivan, 2004; Warin et al., 1999). Findings confirmed to some extent that policy-makers, as well as partners, are on a more involved role for fathers. Fathers have to make sense of their role, and in doing so reflect on and adapt to their own circumstances and to the variety of different models with which they are now presented (Beck \& Beck-Gernsheim, 2002) (cited in Williams, 2008, p. 488).

\subsection{The Role of Parents in the Psychological Development of Children}

The interaction and coordination of the two parents based on the commitment, responsibility, readiness, and time they have to spend with their children is of great importance, as it has a direct impact on the cognitive, emotional, physical development, and economic support of the child. For the purpose of achieving this goal, the Family Code of the Republic of Albania, Article 3, stipulates that: "Parents have the duty and right to take care of the well-rearing, development, welfare, education and upbringing of children born in the wedlock or out of wedlock". It also stipulates that: "The state and society must provide the necessary support to families to keep their children 
in their bosom, to prevent their mistreatment and abandonment, and to maintain the stability of the family" (Family Code, Official Publication, 2012). Also, article 102, point b, clearly states that "parents are the persons obliged to provide food to their children, while article 196 (impossibility to provide alimony) of this Code stipulates that: "Parents are not relieved by the obligation to feed their children even if they have been deprived of parental responsibility" (Family Code, 2012). "Family separation often pervades a period of acute stress and the quality of parenting is likely to be detached during this period, resulting in lower levels of affective behavior, poorer communication, and a more disordered discipline (Hetherington et al., 1982; cited in Rodgers \& Pryor, 1998; and Mackay, 2005) (Cited in: Mooney Oliver \& Smith Coram Th., 2009, page 12).

The early years of life are critical to a child's development and wellbeing, and it lays the groundwork for acquiring skills that influence their behavior, health and learning. Early interventions to promote child development during this critical period have long-term benefits throughout the lives of our children (Moisiu, Tushe, Naqi, Ceka \& Spahiu, 2005). Consequently, it can be said with conviction that both parents serve as the main teachers in the child's life. They assist him in the process of daily learning and influence his formation in the long run.

This paper shows that children with divorced parents from age 13-18 years, in the city of Tirana, strongly feel the lack of the family and that of the fathers figure. Hence, this affects their well-being in their daily lives. This lack is because the vast majority of them live with their mother, and they mostly have no contact with their fathers. The frequency of meeting with him affects the formation of the child and increases his insecurity to establish lasting and long-term love relationships, as well as to perceive a brighter future than that of their parents, or peers coming from intact families. Hence, "it is necessary to assess how divorce changes the total configuration of resources and stressors in the lives of children" (Amato, 1994, p.152). Also, "the real challenge for parents is to help their children grow and not just look like adults" (Neufeld \& Mate, 2006).

Studies have shown that fewer adjustment problems and improved academic achievement are also associated with having a good relationship with the nonresident parent, usually the father. Although the quality of the relationship appears to be more important than the frequency of contact with the non-resident parent, frequent contact is likely to sustain good relationships and vice versa (Mooney et al., 2009, p.2).

The frequent presence of the father and having a positive and supportive relationship on his part would influence and help the child in the process of daily learning as well as help him to create a positive image of himself and his future too. 
Teaching is a social learning process by which an individual modifies his or her behavior in the presence of a learner to increase the probability that the learner acquires information more easily than without teaching or accesses information that would otherwise be inaccessible by individual, trial-and-error learning (Boyette \& Hewlett, 2017) (cited in, Lee Gettler, Adam Boyette \& Stacy Rosenbaum, p.150).

\section{Purpose and Objectives of the Study}

\subsection{Effects on Children}

The aim of this study is to measure the extent to which children with divorced parents experience parental divorce and the lack of a paternal figure in establishing lasting and long-term relationships, and creating a positive perception of their future as adults. This is seen in the context of creating a healthy family, which will not end in divorce just like the relationship of their parents, compared to the perceptions of children coming from families with non-divorced parents.

It also aims to answer specific questions through the completion of the questionnaire by children, both with divorced and non-divorced parents, to obtain a concrete comparative result between them. Questions for children with divorced parents are as follow:

- Do divorce and the lack of a father figure affect the inner world of the children coming from non-divorced families?

- Do children with divorced parents believe that their relationship will be more successful than that of their parents compared to children from intact families?

- Do children with divorced parents believe that their relationship will be more successful than that of their friends from intact families?

- Does the child with divorced parents believe in love?

The same questions above were addressed to children coming from non-divorced families except the part of specific questions about divorce issues.

From the demographic data obtained during the completion of the questionnaire, the results show that $77.23 \%$ of children live with the mother, which means that most of them grow up without the presence of a father in their daily life. Thus, the question which naturally arises is: Why is the role of the father so important in the life of a child?

Despite a diversity of views, the research suggests seven dimensions of fathering: a) Fostering a positive relationship with the children's mother, b) Spending time with children, c) Nurturing children, d) Disciplining children appropriately, e) Serving as a guide to the outside world, f) Protecting and providing, g) Serving as a positive role model (Rosenberg \& Wilcox, 2006, 
p.19). According to this, the child with divorced parents misses the following important assets of a father:

a) The Feeling and Affection of Having a Father: In order not to be bullied by society and peers in general, it is very important for the child to feel the support of the father as an umbrella that protects him from the difficult and unexpected storms of life.

b) Support in Life and Education: Fathers of adolescents should incorporate discussions of their core beliefs and life experiences into ordinary conversations with their teens and have meals with their children on a regular basis. Also they should spend time fostering their children's intellectual growth (Rosenberg \& Wilcox, 2006, p. 19-21).

c) Influential in Life through his Remarks and Suggestions: From birth to growing up, the child needs a leader who shows him the way on how he should act to achieve goals and objectives during the stages of life. This leader serves as a guide to the child because it is difficult for the divorced mother to take care of the children alone after divorce.

d) The Father Provides Financial Security in the Child's Life: Historically, since the beginning of patriarchal society, the main role of the father was to provide food and financial income for his wife and children, while the mother took care of the children and their wellbeing inside the house. Even though society has evolved and nowadays gender equality is aimed at, financial hardship is a daily challenge for a divorced mother. This is because the household budget is reduced compared to when both spouses contributed, or it may even get worse when the mother becomes unemployed.

\section{Methodology}

The participants included in the study are children between 13-18 years of age in public schools in Tirana. Children are divided in two categories: children with divorced parents and those with non-divorced parents. Information about the number of children with divorced parents was obtained through school psychologists, who keep the data of children in the school social map, which is part of their work procedure. The research population was schools in the city of Tirana, both elementary and high schools.

The sample was made up of 19 public schools which were identified to have the highest number of children with divorced parents, 9 of which were elementary, and the rest were high schools. 500 questionnaires were distributed, of which 405 questionnaires were answered and returned. The results obtained are as follows: $39.51 \%$ were boys and $60.49 \%$ were girls. The children from intact families were randomly selected from the same schools (See the data below): 


\begin{tabular}{|c|c|c|}
\hline Description & Percentage & Total number \\
\hline Total Sample Schools & $19(100 \%)$ & 19 public schools $^{1}$ \\
\hline Elementary Schools (Divorced + Non-divorced) & 9 & 225 \\
\hline High Schools (Divorced + Non-Divorced) & 10 & 585 \\
\hline Total No of children with divorced parents & $405(100 \%)$ & 405 \\
\hline Total Boys & $39.51 \%$ & 160 Boys \\
\hline Total girls & $60.49 \%$ & 245 Girls \\
\hline Total No of children from intact families & $405(100 \%)$ & 405 \\
\hline Total Boys & $38,77 \%$ & 157 children \\
\hline Total Girls & 61,23 & 248 children \\
\hline
\end{tabular}

The questionnaires are completed by the children with divorced and non-divorced parents in the presence of the school psychologist in order to be in accordance with all applicable laws of the Albanian state for the protection of children's rights.

Both categories of children completed a socio-demographic questionnaire with the general information about gender, age, and classroom. Hence, the specific one is as follows:

- Who do you live with?

- Do you believe in love?

- Do you believe that your future (life) will be better than that of your parents?

- Are you confident that your relationship will be more successful than that of your parents?

- Are you confident that your relationship will be more successful than that of your friends?

- Consequently, children with divorced parents were asked the above questions and the following specific one:

- How often do you meet the non-custodial parent?

Methodology and questionnaire was based on long-term and qualitative studies of western countries who have studied the phenomenon of parental divorce in detail throughout the various stages of the child's life.

In their book, Growing up with a single parent, Sara McLanahan and Gary Sandefur say: "We argue that growing up with only one biological parent frequently deprives children of important economic, parental and community resources, and that these deprivations ultimately undermine their chances of future success. We view the lack of parental and community resources as a deficit in what the sociologist James Coleman calls social capital. Social capital is an asset that is created and maintained by relationships of

${ }^{1}$ Identified on the basis of the highest number of children from divorced parents 
commitment and trust. It functions as a conduit of information as well as a source of emotional and economic support, and it can be as important as financial capital in promoting children's future success" (Mc Lahanan \& Sandefur, 1994, p.3).

'Direct parental care can positively influence children's outcomes in a number of ways (Gettler, 2010; Hewlett, 1993) (cited in: Lee Gettler et al., 2020, p.148).

In summary, "family social capital in general, and fathers' social capital in particular, can feel the benefits of children's health, psycho-social development and social opportunities, and can be a hereditary resource that enables them (you provide benefits) in some settings" (Chaudhary et al.,2016; Smith et al.,2010) (cited in: Lee Gettler et al., 2020, p.148).

\section{Purpose}

A noted sociologist, Dr. David Popenoe, is one of the pioneers of the relatively young field of research into fathers and fatherhood. He confirms: "Fathers are far more than just "second adults' in the home," "Involved fathers bring positive benefits to their children that no other person is as likely to bring" (Rosenberg \& Wilcox, 2006, p. 11).

The purpose of this study is to determine through scientific methodology to what extent children experience parental divorce and the lack of the father figure, and the impact it has on the psycho-social consequences on children aged 13-18 years in Tirana, Albania.

\subsection{Difficulties of Working}

From the beginning of the work, there have been difficulties in finding information on the exact number of children with divorced parents in the city of Tirana. The place of residence for both spouses after the divorce often changes. Therefore, the identification of the exact number of children is done approximately through contact with school psychologists who record the number of children with divorced parents on the social map that they keep as work for the learning process. In each school, the total number of children with divorced parents was taken into consideration and there were no other data of sensitive character that could identify the child, thus conforming to the law on protection of sensitive data. Also, the complete anonymity of the children was maintained during the completion of the questionnaire for both categories of children with divorced and non-divorced parents. 


\section{Findings}

\subsection{Analysis of Questionnaire Data for Children with Divorced Parents Compared to Children with Non-Divorced Parents}

Demographic Information: The sample between two groups of children is almost equal in terms of gender. The results obtained from 405 respondents children with divorced parents (CHDP) are as follows: 60,5\% of the population were females compared to $39.5 \%$ male, while $61,23 \%$ of the population of CHNDP were females compared to male $38,77 \%$.

Belief in Love: Parental separation serves as a negative model for trust in love. The percentage of children with divorced parents who do not believe in love is significantly higher compared to that of children with both parents. $36.91 \%$ of CHDP do not believe in love, while $63.09 \%$ of them believe in it versus $19.05 \%$ of CHNDP who do not believe in love, and $80.95 \%$ of them who believe in it.

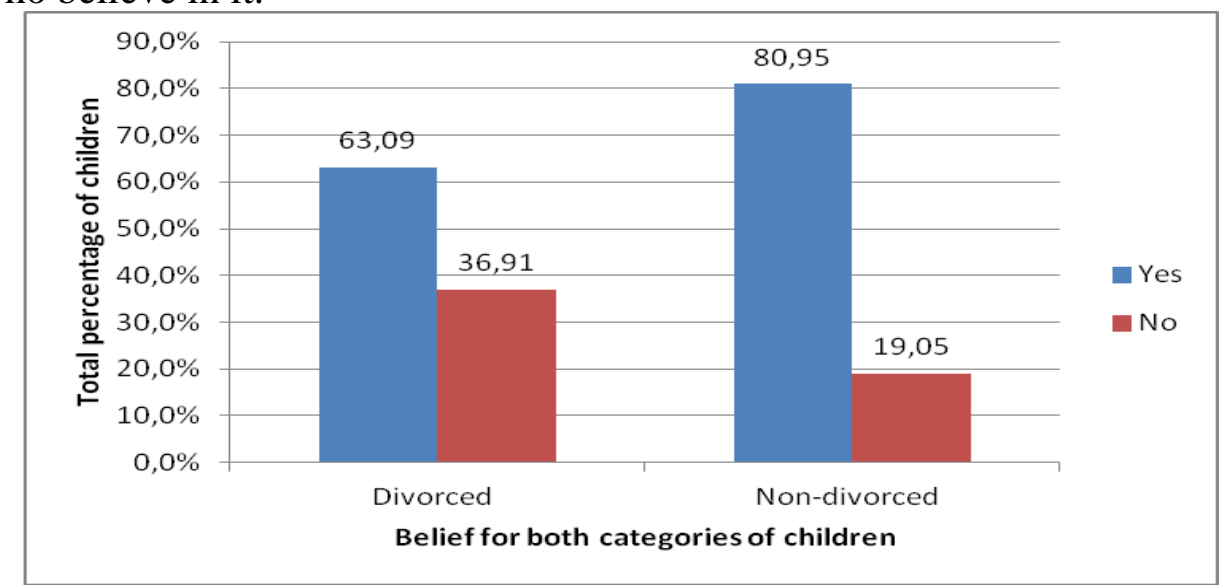

Table 1. Belief in Love

Belief in Future: Children with divorced parents have lower expectations rates that their future would be better than that of their parents compared to children coming from non-divorced families. The failure of parental marriage and the decrease of incomes make CHDP to negatively perceive a better future than that of their parents. The answers are shown below:

$6.23 \%$ of CHDP never believe that their future will be better than that of their parents, while $13.97 \%$ answered they believe it sometimes, $10.97 \%$ answered to believe it many times, $22.19 \%$ answered they believe most times, and $46.63 \%$ of them always believe in a better future $2.2 .07 \%$ of CHNDP

\footnotetext{
${ }^{2} 1$ - Never

2-Few Times

3- Sometimes (Neutral)

4- Most times
} 
answered that they never believe that their future will be better of their parents, while $14.77 \%$ answered they believe sometimes, $9.33 \%$ believe many times, $26.17 \%$ believe most times, and $47.67 \%$ confirm always have faith in a better future than that of their parents.

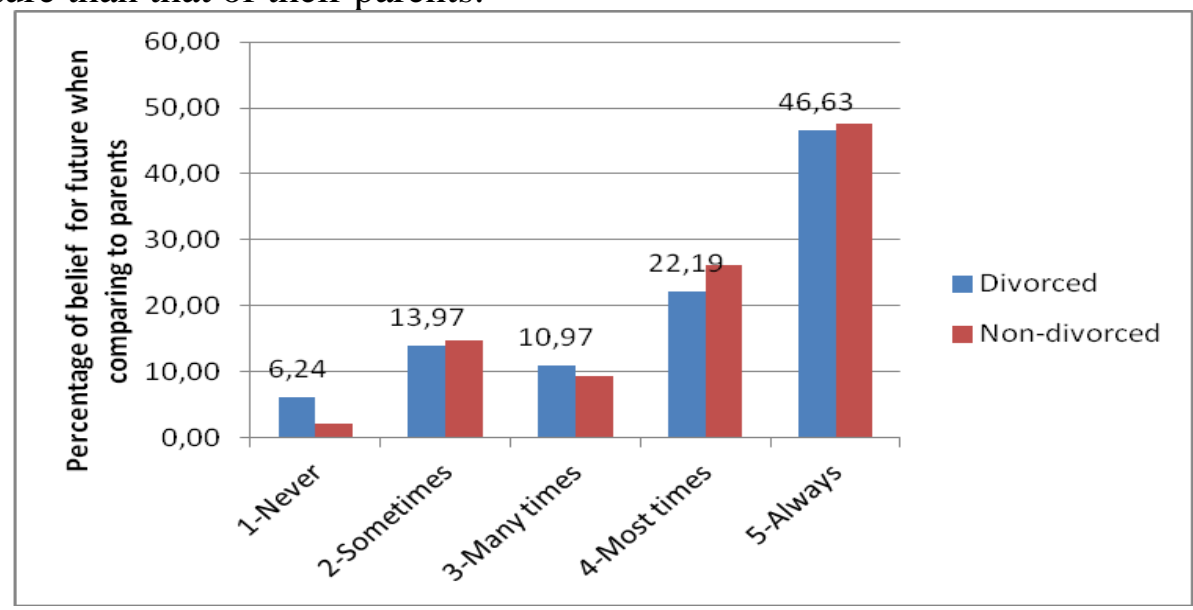

Table 2. Belief in Future

Belief in a Successful Relationship: Intact families are perceived safer from children with divorced parents than families with one divorced parent. They are less confident that their relationship will be more successful than that of their friends. From the survey, 23\% answered they never trust, while $26.61 \%$ answered they believe sometimes, $14.47 \%$ believe it many times, $20.16 \%$ answered to believe it most times, and $15.76 \%$ said they always believe in a better future than that of their friends.

$6.93 \%$ of CHNDP answered they never believe, while $10.4 \%$ answered they believe sometimes, $7.43 \%$ believe it many times, and $23.51 \%$ answered to believe most times. Meanwhile, 51.73\% confirmed they always believe in a better future than that of their friends.

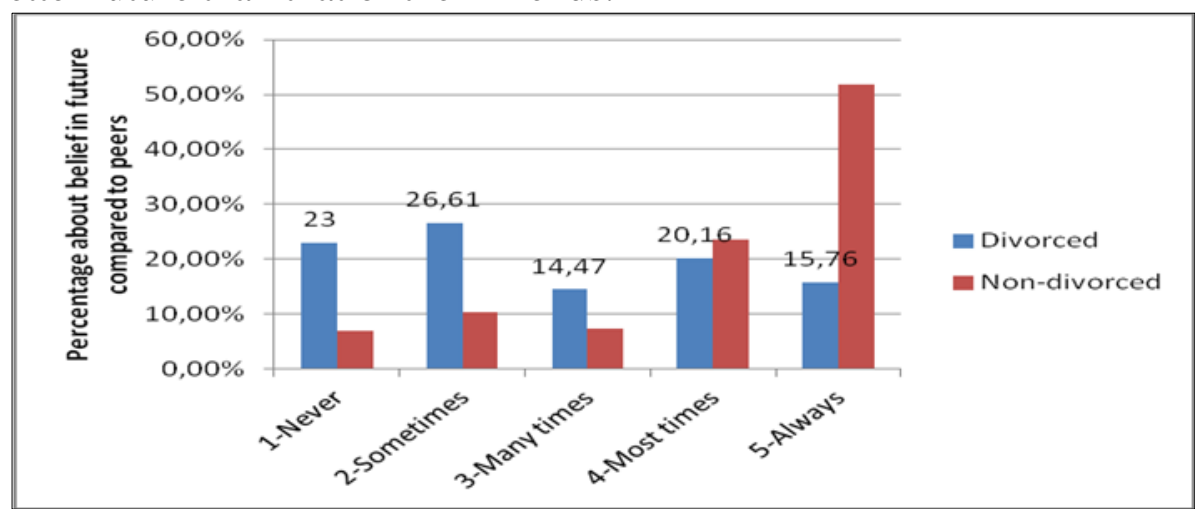

Table 3. Belief for Long-Term Love Relationships

5- Always 
Payment of Financial Obligation from Non-Custodial Parent: From the 405 respondents, only $98.02 \%$ have responded. Out of them, $51.85 \%$ confirmed that the non-custodial parent never pays the financial obligation and only $16.3 \%$ of them contribute everyday financially. Meanwhile, $3.7 \%$ pay it once a month and $2.47 \%$ pay it more than once a month. $23.7 \%$ contribute once a week. In general, it means that more than half of the divorced children and their family members suffer lower economic income compared with that before divorce.

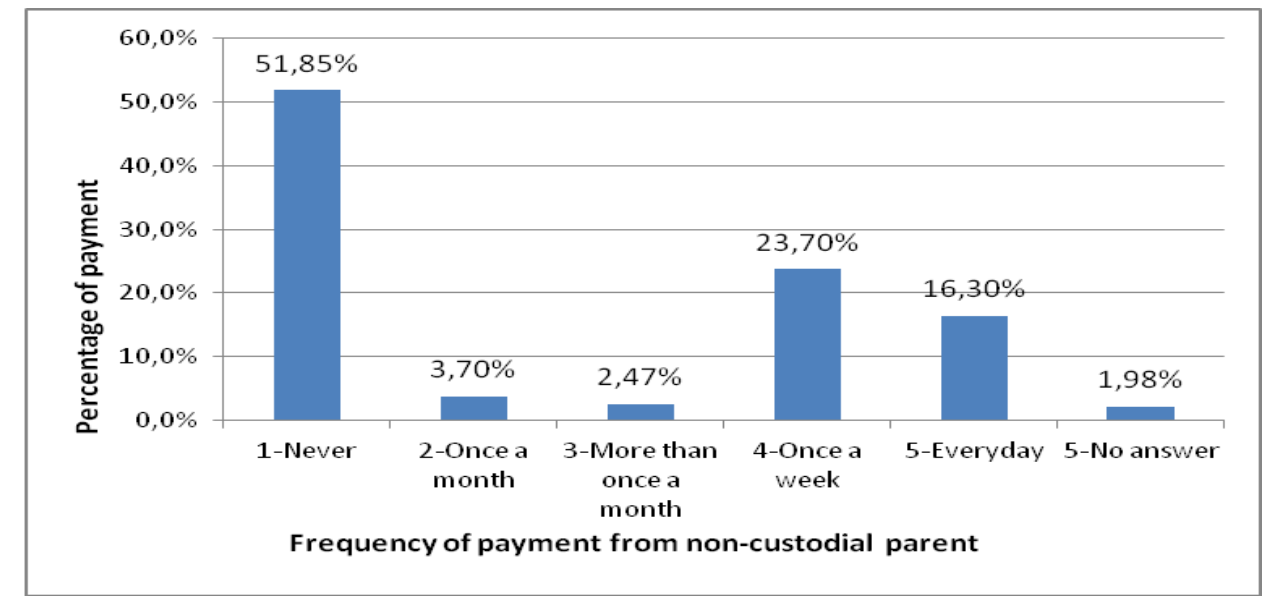

Table 4. Payment of Financial Obligation from the Non-Resident Parent

Frequency of Meeting the Non-Custodial Parent: The data show a bitter truth of the reality as $36.81 \%$ of the respondents have never met their non-custodial parent, while $5.01 \%$ of the sample have not responded.

The refusal to not answer this question indirectly means that even this category of children has no contact at all with the non-custodial parent, or they do not have a good relationship with each other. Only $15.14 \%$ of the whole sample indicated that they have daily contact with the non-custodial parent, and $20.07 \%$ have confirmed to meet once a week and $17.23 \%$ meet him/her more than once a week.

The destruction of social capital will weaken the bond between the child and the father. When the father lives in another home, he is less devoted and committed to his child and less trusting towards his child's mother. As a result, he will be less willing to invest time and money on his child's wellbeing ${ }^{3}$. 


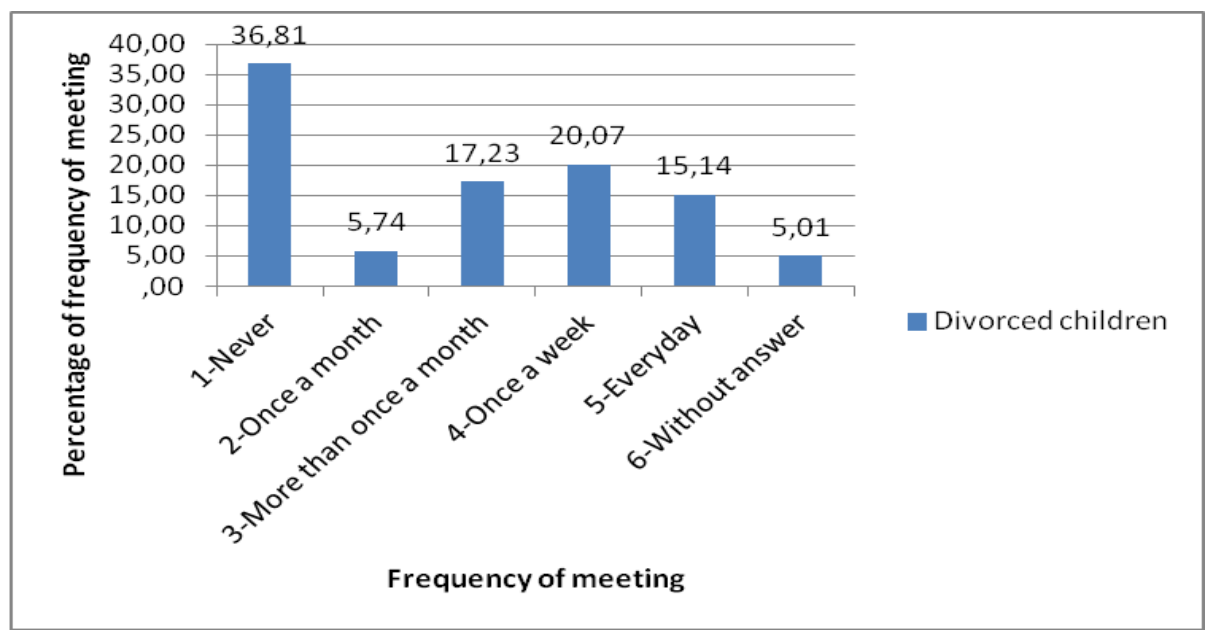

Table 5. Frequency of Meeting the Non-Custodial Parent

\section{Conclusion}

From data obtained in this study, it can be concluded that there are differences in perception between children with divorced parents and those coming from intact families in the city of Tirana, which is the most developed city and has got the biggest population in Albania ${ }^{4}$. These differences lead children with divorced parents to have more negative perceptions and lower expectations than those of their peers coming from non-divorced families in terms of trust in love and self-esteem. Hence, these lower perceptions make children have lower expectations in believing in a better future when compared with the expectations of children living with both parents.

For more than half of the children, it resulted that the non-custodial parent never paid the financial obligation assigned by the court. Economic deprivation and the frequency of meeting with the non-custodial parent is decisive for the children's perceptions about the future.

\section{Recommendations}

Based on the data of the study and the conclusions drawn, it is first recommended to open free psychological counseling centers for children with divorced parents. The child can receive psychological help at these centers at any time as it is very necessary for him to get acquainted with the changes that his new post-divorce life will undergo. It is very important to let the child know that he is not responsible or the culprit for the occurrence of the parents' divorce in order to increase self-confidence and self-esteem, thus equalizing him/her with the children who do not come from divorced families.

${ }^{4} \mathrm{http} / / /$ www.instat.gov.al/al/temat/treguesit-demografik\%C3\%AB-dhesocial\%C3\%AB/popullsia/publikimet/2021/popullsia-e-shqip\%C3\%ABris\%C3\%AB-1janar-2021/ 
Second, the state must implement the appropriate mechanisms and ways for all fathers of children with divorced parents to pay correctly the economic obligation imposed by the court for the upbringing of the child, and to be regular in visitations with them. In order to improve the quality of relationship between them, father and child should not only meet on courtappointed days (usually weekends), but also more often in order for their relationship to be strengthened and the child to feel the presence and support of both parents alike as if the family had not been separated.

Third, it is recommended to create a special fund in the state budget as a separate item to help children with divorced parents, because until this moment there is no such assistance. This budget would have a direct impact on improving the quality of life of divorced mothers and their children.

\section{References:}

1. Beqja, H. \& Sokoli, L. (2000). Divorci, Vrojtime e Refleksione, (C) Dudaj dhe Rinia 2000

2. Connor, J. (2007). The Sociology of Loyalty, (C) Springer Science Business Media, LLC,

3. Gettler, T. L., Boyette, H. A. \& Rosenbaum, S. (July 2020). Broadening Perspectives on the Evolution of Human Paternal Care and Fathers Effects on Children, Copyright $(92020$ by Annual Reviews First published as a Review in Advance on July 13, 2020 https://www.annualreviews.org/doi/pdf/10.1146/annurev-anthro102218-011216

4. Kodi i Familjes dhe Legjislacioni për Birësimet $i$ Republikës së Shqipërisë, Botim i Qendrës së Publikimeve zyrtare, Shtator 2012.

5. McLahanan, S. \& Sandefur, G. (2005). Growing Up with a Single Parent, Harvard University Press, Cambridge Massachusetts, London England.

6. Moisiu, R., Tushe, E., Naqi, D., Ceka, N. \& Spahiu, L. (2005). Arti $i$ rritjes së fëmijëve, Çdo gjë që duhet të dini nga shtatëzania deri në moshën 6-vjeçare, Unicef dhe Ministry of Health, Tiranë, Pegi Publishing House \& Printing House

7. Mooney, A., Oliver, C., Smith, M. \& Coram. T. (2009). Research Unit, Institute of Education, University of London Impact of Family Breakdown on Children's Well-Being, https://dera.ioe.ac.uk/11165/1/DCSF-RR113.pdf

8. Neufeld, G. \& Mate, G. (2006). Hold on to your Kids, Ballantine Books

9. Paulo Amato, R. (1994). The future of children, Life-Span Adjustment of Children to Their Parents' Divorce 
10. Rosenberg, J. \& Wilcox, W. B. (2006). The Importance of Fathers in the Healthy Development of Children (Child abuse and manual series), US Department and Human Services, Administration for Children and families, Children's Bureau, Office on Child Abuse and Neglect

11. http://www.instat.gov.al/al/temat/treguesit-demografik\%C3\%ABdhe-social\%C3\%AB/popullsia/publikimet/2021/popullsia-eshqip\%C3\%ABris\%C3\%AB-1-janar-2021/

12. http://databaza.instat.gov.al/pxweb/sq/DST/START_BD_MAR/Ne wMa_003/?rxid=3fc44eb5-0a09-44ae-9f5e-d47eba61960b

13. https://downloads.frc.org/EF/EF12A22.pdf 